\title{
Kaidah Rasm Hazf Alif dalam Mushaf Standar Indonesia dan Mushaf Kuno Koleksi Pondok Pesantren Tebuireng
}

\author{
Adrika Fithrotul Aini \\ Islam IAIN Tulungagung \\ adrikaaini01@gmail.com
}

Diterima 15 Februari 2020 | Direview 27 April 2020 | Diterbitkan 30 Juni 2020

\begin{abstract}
:
This study describes the model of the use of the rule of rasm in hasf and itsbat alif in three letters, namely the letter Yasin, arRahman, and al-Waqiah. The object of this research study is the Indonesian standard Manuscripts (MSI) made by the Ministry of Religion and ancient Manuscripts in the Tebuireng Islamic Boarding School (MQT). The taking of these two Manuscripts is intended as a first step to see the development of the use of rasm in Manuscripts in Indonesia, starting from the ancient Manuscripts until the formation of Indonesian Manuscripts. From the results of the analysis of researchers in seeing the application of haif and itsbat alif rules on the two Manuscripts, it concludes that the Indonesian standard Manuscripts do the mixed rules in writing alif. While the ancient Manuscripts collection of Tebuireng Islamic boarding schools are more likely to make alif (itsbat) assignments

Keywords: Rasm rules, Itsbat alif, Havif Alif, Indonesian Standard Manuscripts, Tebuireng Manuscripts.
\end{abstract}

\begin{abstract}
Abstrak:
Penelitian ini memaparkan mengenai model penggunaan kaidah rasm dalam haर्रf dan itsbat alif pada tiga surat, yakni surat Yasin, ar-Rabman, dan al-Waqiah. Objek kajian penelitian ini adalah mushaf standar Indonesia (MSI) yang dibuat oleh Kementrian Agama dan mushaf kuno yang ada di pondok pesantren Tebuireng (MQT). Pengambilan dua objek mushaf ini bertujuan sebagai langkah awal melihat perkembangan penggunaan rasm dalam mushaf di Indonesia yang dimulai dari mushaf kuno sampai terbentukny a mushaf standar Indonesia. Dari hasil analisis peneliti dalam melihat penerapan kaidah hasf dan itsbat alif pada dua mushaf tersebut menghasilkan kesimpulan bahwa mushaf standar Indonesia melakukan kaidah campuran dalam penulisan alif. Sedangkan mushaf kuno koleksi pondok pesantren Tebuireng lebih cenderung melakukan penetapan (itsbat) alif.
\end{abstract} Kata Kunci: Kaidah rasm, Itsbat alif, Havif Alif, Mushaf Standar Indonesia, Mushaf Tebuireng.

\section{Pendahuluan}

Penulisan dan penyalinan mushaf al-Qur'an sudah dilakukan semenjak masa Rasulullah sampai sekarang. Di Nusantara, proses penyalinan al-Qur'an berkembang seiring dengan berkembangnya ajaran Islam di berbagai wilayah, dari bagian utara sampai ujung Nusantara bagian Timur. Penyalinan yang berkembang semenjak berkembangnya Islam di nusantara dibuktikan dengan banyaknya koleksi manuskrip mushaf di beberapa museum, perpustakaan, masjid, pondok pesantren, maupun koleksi pribadi. Berbagai macam bentuk manuskrip mushaf juga memberikan karakter tersendiri bagi setiap naskahnya, baik dari segi keindahan iluminasi, bentuk naskahnya, bahkan teks dari ayat-ayat al-Qur'annya. Beberapa hal yang penting diulas dari sebuah naskah adalah karakter penulisan rasm, dabt, waqaf, atau tajwidnya. Hal ini juga menunjukkan banyaknya variasi mushaf yang tersebar di Nusantara. Hal ini menjadi kegelisahan tersendiri bagi pemerintahan Indonesia atas banyaknya variasi penulisan al-Qur'an yang menimbulkan kekhawatiran terjadinya perselisihan pendapat dari generasi ke generasi. ${ }^{1}$ 
Kekhawatiran tersebut memunculkan gagasan dibentuknya musyawarah para ulama al-Qur'an pada tahun 1972 yang kemudian melahirkan sebuah kesepakatan dan pedoman keseragaman dalam penulisan ayat-ayat al-Qur'an. Munculnya musyawarah kerja ulama ini juga menjadi tonggak awal wacana penulisan ayat al-Qur'an menggunakan rasm usmani. ${ }^{2}$ Ada tiga mushaf yang menjadi keputusan musyawarah para ulama dalam penyusunan mushaf standar, yakni mushaf standar Indonesia bagi orang awam, mushaf Bahriyyah bagi penghafal, dan mushaf Braille bagi disabilitas. Dengan hadirnya standar mushaf tersebut, hampir semua percetakan tidak lagi ada perbedaan signifikan dalam penyalinan dan penerbitan mushaf al-Qur'an.

Meskipun sudah ada mushaf standar, namun kenyataannya penemuan manuskrip mushaf al-Qur'an peninggalan nenek moyang masih banyak ditemukan di berbagai daerah, seperti halnya yang peneliti temukan di pondok pesantren Tebuireng. Peneliti menemukan manuskrip ini di perpustakaan pondok. Peneliti tertarik melakukan kajian terhadap manuskrip mushaf ini dari segi pembahasan karakter rasmnya. Akan tetapi peneliti tidak mengulas secara keseluruhan dari dua mushaf ini dalam melihat karakter rasmnya, akan tetapi hanya pada tiga surat yang familiar di kalangan masyarakat Indonesia, yakni surat Yasin, ar-Rahman, dan al-Waqiah. Pengambilan tiga objek surat ini bertujuan melihat bagaimana bentuk penulisan atau rasm yang familiar pada masa lalu dan seberapa jauh perbedaan dan persamaannya dengan mushaf standar yang telah dijadikan pedoman masyarakat di era sekarang.

Dalam beberapa kajian, penelitian tentang mushaf standar Indonesia masih terbatas dan minim. Mayoritas penelitian fokus pada mushaf standar Indonesia yang dibandingkan dengan mushaf Madinah, mushaf Pakistan, maupun mushaf Turki. Peneliti belum menemukan kajian terhadap karakter penggunana rasm standar Indonesia disandingkan dengan manuskrip mushaf al-Qur'an kuno. Beberapa literatur yang peneliti temukan kebanyakan membahas secara tersendiri, baik kajian tentang mushaf standar Indonesia maupun manuskrip mushaf al-Qur'an kuno. Dari terbatasnya literatur yang membandingkan manuskrip mushaf al-Qur'an kuno dengan mushaf standar menjadikan peneliti tertarik untuk melakukan kajian ini, namun dengan membatasi pada kajian rasm, yakni kaidah ha:f alif. Hal ini dikarenakan, penulisan secara kaidah dalam bahasa Arab pembuangan atau penetapan huruf alif banyak terjadi perbedaan dalam penulisn kaidah rasm usmani.

\section{Sejarah Penulisan al-Qur'an}

Perbincangan penulisan al-Qur'an di era awal, tidak bisa terlepas dari pembahasan pada saat masa Nabi dan Abu Bakar. Masa ini disebut dengan masa rintisan, karena di masa inilah orang-orang (sahabat) mengenal tulisan al-Qur'an yang selama ini dilafalkan secara oral bukan tulisan. Pada masa Nabi, rintisan penulisan alQur'an ini dimulai dengan penulisan di beberapa media sederhana seperti lontar (riqa), batu, pelepah kurma ('asib), tulang, kulit binatang, dan media sederhana yang lainnya. ${ }^{3}$ Apabila dipetakan dalam periodesasi, penulisan al-Qur'an ini dimulai pada tahun 571$632 \mathrm{M}$ atau 53 tahun sebelum dan 11 tahun setelah hijrah. Pentingnya penulisan alQur'an pada waktu itu dapat dilihat dari Nabi yang melarang para sahabat untuk tidak menuliskan sesuatu selain ayat-ayat al-Qur'an. Hal ini dilakukan oleh para sahabat

${ }^{2}$ Ibid.

${ }^{3}$ Taufik Adnan Amal, Rekonstruksi Sejarah al-Qur'an, (Jakarta: Pustaka Alfabet, 2005), 176-177. 
sampai al-Qur'an ditulis secara lengkap. Sumber tulisan al-Qur'an tersebut dari para qurra' atau huffadz. ${ }^{4}$

Buku Manahilul 'Irfan karya Imam az-Zarqani menjelaskan bahwa kondisi seperti itu memang menjadi ciri pada masa awal Islam. Meskipun sudah ada suatu tulisan, akan tetapi itu menjadi koleksi individu. Data ini bisa dibuktikan dengan data yang dipaparkan oleh Mustofa A'zami yang mengatakan bahwa sampai menjelang Nabi Muhammad akan wafat, ada 48 orang yang ahli dalam bidang tulis menulis. ${ }^{5}$ Beberapa penjelasan tersebut memperlihatkan bahwa pada masa awal Islam, fokus yang ditekankan oleh Nabi Muhammad adalah bukan pendokumentasian, akan tetapi perekaman dalam diri setiap sahabat atau umat Islam.

Era kedua yakni era khulafaur rasyidin yang diawali dengan era kekhalifahan Abu Bakar. Pada masa kepemimpinan Abu Bakar, umat Islam mengalami banyak problematika, seperti pengkhianatan, peperangan, dan pemurtadan. Beberapa peristiwa tersebut dikarenakan terbatasnya para penghafal al-Qur'an yang semakin masa semakin menua, maka Umar bin Khattab mengalami kegelisahan atas pendokumentasian alQur'an. Dari kegelisahannya tersebut, ia menghadap Abu Bakar dan memberikan usulan bahwa perlu adanya pendokumentasian al-Qur'an dalam bentuk fisik. Setelah terjadi perdebatan antara Abu Bakar dan Umar, maka diputuskan bahwa Abu Bakar memberi persetujuan kepada Umar untuk melakukan pendokumentasian tersebut. Dari beberapa pertimbangan, ditunjuklah Zaid bin Tsabit sebagai penulis al-Qur'an. Maka, pada abad $7 \mathrm{M}$ atau $12 \mathrm{H}$, mulai munculnya al-Qur'an dalam bentuk kumpulan tulisan jadi satu yang disebut dengan subuf.

Subuf ini dalam data sejarah hanya satu dan berpindah pemegangnya setelah kepemimpinan Abu Bakar. Umar bin Khattab lah yang menjadi 'ahli waris' subuf tersebut sampai ia meninggal dunia. Pada era Umar bin Khattab tidak ada penulisan lagi mengenai al-Qur'an, melainkan mulai muncul perbedaan pendapat dari para penghafal al-Qur'an mengenai bacaan al-Qur'an. Lihat saja data sejarah yang ada dalam buku Mustafa A'zami yang mengatakan bahwa Umar bin Khattab marah kepada Ibnu Mas'ud yang mengajarkan bacaan al-Qur'an dengan dialek Huzail. ${ }^{6}$ Perbedaan bacaan yang menjadi perselisihan ini difaktori oleh subuf yang disusun pada saat itu memang tidak ada tanda bacanya dan masa Nabi masih hidup pun tidak ada penyalahan terhadap bacaan para sahabat yang berbeda. Kemudian, sepeninggal Umar bin Khattab Subufini dipegang oleh istrinya, yakni Hafsah.

Legalitas atas solusi terhadap perselisihan mengenai perbedaan bacaan al-Qur'an ada pada masa Usman bin Affan. Era inilah muncul istilah rasm usmani. Legalitas rasm usmani ini diawali dengan perselisihan sebagaimana yang terjadi pada era Umar bin Khattab. Akan tetapi, pada era Usman ini bukan khalifah Usman yang marah terhadap para qurra' tersebut, akan tetapi para qurra' saling mengkafirkan atas perbedaan bacaan mereka. Seorang sahabat yang bernama Huzaifah melaporkan kejadian tersebut kepada Usman, dan mencari solusi atas perselisihan tersebut yang apabila tidak dicarikan solusi akan terjadi lagi pada era berikutnya dan berikutnya. Langkah awal yang dilakukan Usman adalah dengan cara meminjam subuf yang dipegang oleh Hafsah. Langkah berikutnya adalah melakukan pendokumentasian ulang mengenai bacaan al-Qur'an

${ }^{4}$ Subhi Salih, Mabahits fi Ulum al-Qur'an, (Beirut: Dar Ilm al-Malayin, 1997), 8-9.

${ }^{5}$ Muhammad Mustafa A'zami, Kuttab Nabiy, (Beirut: al-Maktab al-Islamy, 1978).

${ }^{6}$ Muhamamd Mustafa A'zami, The History of The Qur'anic Text from Revelation to Compilation, 87. 
yang tetap sama dikoordinatori oleh Zaid bin Tsabit. ${ }^{7}$ Pendokumentasian di era ini bukan hanya kepentingan sebagai dokumentasi semata, akan tetapi bagaimana caranya ada bentuk legal kodifikasi al-Qur'an yang dapat meredakan perselisihan bacaan. Diputuskanlah solusi, bahwa perlu melakukan pendokumentasian yang dapat mencover semua perbedaan bacaan yang tidak dapat dielakkan.

Hasil pendokumentasian ulang yang tujuannya adalah untuk mendamaikan perselisihan agar tidak berlanjut di masa mendatang, maka konsep hasil dokumentasian ini bukan hanya sebagai koleksi pribadi era Usman, akan tetapi dilakukan pendistribusian ke berbagai daerah, seperti Makkah, Madinah, Syam, Kuffah, dan Basrah. Diseminasi mushaf al-Qur'an tersebut disertasi dengan pemusnahan mushafmushaf lain yang selain disusun oleh Zaid bin Tsabit dan Tim. Hal ini bertujuan untuk menghinari perselisihan kembali muncul sebagaimana sebelumnya

Diseminasi ke berbagai daerah, ada tugas seorang qurra' yang melakukan penyebaran ini, di antaranya adalah:

1. Makkah: Abdullah bin as-Sa'ib

2. Madinah: Zaid bin Tsabit

3. Syam: al-Mughirah bin Abi Syihab

4. Kufah: Abdurrahman bin Habib al-Sulami

5. Basrah: Amir bin Abdul Qais

6. Mushaf yang dipegang Usman bin Affan

Namun, banyak perbedaan pendapat mengenai jumlah dokumentasi mushaf era Usman ini. Data ini dapat dilihat dalam bukunya Abu Amr ad-Dani, al-Suyuti, dan alJazari. Dalam data di buku mereka dijelaskan bahwa jumlah mushaf Usman bukan hanya 6, al-Jazari mengatakan berjumlah 8 , al-Suyuti mengatakan 5 mushaf, dan adDani mengatakan 4 mushaf.

Setelah pengerjaan kodifikasi pada era Usman bin Affan, tujuan yang ingin dicapai dapat terlaksana. Umat Islam sudah tidak lagi berselisih mengenai penulisan mushaf al-Qur'an maupun bacaan al-Qur'an. Penyebaran mushaf al-Qur'an dan bacaan al-Qur'an dapat berjalan dengan damai tanpa ada perselisihan. Namun, perselisihan memang tidak dapat dielakkan, sehingga pada masa Dinasti Umayyah, muncullah permasalahan baru yakni tentang tanda baca al-Qur'an. Pada masa inilah subuf yang disimpan Hafsah dimusnahkan. Tujuan pemusnahannya adalah untuk tidak menimbulkan perselisihan baru, karena sudah ada mushaf Usmani. ${ }^{8}$

Apabila melihat secara filologis dari berbagai mushaf al-Qur'an dari era ke era, bahwa mushaf Usman merupakan mushaf yang ditulis di atas kulit binatang. Sedangkan bentuk khat atau kaligrafi yang digunakan adalah bentuk khat Kufi. Di era Islam pada masa awal, khat yang digunakan memang mayoritas menggunakan bentuk Kufi. ${ }^{9}$

Dari usainya kodifikasi dan legalisasi pada masa Usman, tidak ada lagi proses perubahan legalisasi mushaf al-Qur'an. Hal ini menunjukkan langkah legalitas era Usman bin Affan menuai keberhasilan. Namun, pada kenyataannya, dari berbagai literatur menjelaskan bahwa sejak dulu tidak semua mushaf al-Qur'an yang tersebar pasti berbasis rasm usmani. Ada beberapa mushaf yang ditemukan di beberapa daerah atau negara yang tidak seluruhnya mengacu pada kaidah rasm usmani.

7Jalal al-Din Abdurrahman al-Suyuti, al-Itqan fi 'Ulum al-Qur'an, (Beirut: Dar al-Fikr, 1951), 56. ${ }^{8}$ Subhi Shalih, Mabahits fi Ulum al-Qur'an, (Beirut: Dar al-'Ilm li al-Malayin, 1985), 82.

${ }^{9}$ Didin Siradjuddin AR, Seni Kaligrafi Islam, (Bandung: PT. Remaja Rosdakarya, 2000), 79-80. Khat Kufi adalah khat warisan dari bangsa Smith dan menjadi cikal bakal munculnya khat kontemporer. 


\section{Definisi Kaidah Rasm Usmani dan Hukum Penggunaannya}

Rasm adalah cara penulisan yang disepakati pada masa Usman bin Affan. Hal ini yang menjadikan cara penulisannya ini disebut dengan rasm usmani. Dalam kitab Mababits fi 'Ulum al-Qur'an, yang disebut dengan usmani adalah tata cara penulisan yang pernah diterapkan pada masa khalifah Usman bin Affan. Tata cara yang pernah berlaku ini yang di kemudian dijadikan standar dalam penulisan al-Qur'an di berbagai tempat. ${ }^{10}$ Rasm Usmani adalah suatu pola yang menitik beratkan paa metode yang digunakan pada masa kodifikasi al-Qur'an yang dikoordinatori oleh Zaid bin Tsabit. Adapun definisi rasm usmani adalah:

"Rasm Usmani adalah suatu pola dalam penulisan al-Qur'an yang digunakan oleb Usman bin Affan dengan para sababat dengan bentuk-bentuk, tulisan buruf (rasmnya)."11

Tulisan Arab sebenarnya ditulis sesuai dnegan ucapannya, tanpa ada pengurangan maupun penambahan, juga penggantian dan perubahan huruf. Akan tetapi, tata cara penulisan rasm usmani mempunyai ciri khas tersendiri yang berbeda dengan pola penulisan secara umum. Sehingga, ada beberapa kaidah penulisan sesuai ucapan akan tetapi dalam kaidah bahasa Arab tidak sesuai. Ini bukan suatu penyimpangan, akan tetapi pola penulisan seperti ini mempunyai tujuan tersendiri yang disusun pada masa khalifah Usman tersebut. Adapun hukum dalam penggunaan rasm usmani mempunyai perbedaan pendapat. Secara prinsipal, perbedaan pendapat tersebut menyangkut mengenai rasm usmani tauqifiatau taufiqi. Adapun perbedaan para ulama atas pendapat ini adalah sebagai berikut;

1. Jumhur ulama mengatakan rasm usmani adalah tanqifi. Tidak diperbolehkan menggunakan tata cara penulisan selain rasm usmani. Adapun pendapat para ulama ini didasarkan pada adanya seleksi dari Nabi Muhammad terhadap orang yang diperintahkan untuk menulis. Ini menunjukkan bahwa penulisan al-Qur'an itu sudah terjaga dan tidak sembarang orang bisa melakukannya.

2. Ulama yang sepakat tanqifi mengatakan bahwa para sahabat dan beberapa orang tidak ada ikut campur dalam penulisan al-Qur'an. Oleh karena itu, tata cara penulisannya tidak ada kaidah khusus yang dapat menjelaskan secara detail pola tulisan yang menyimpang dari tulisan dalam bahasa Arab.

3. Pendapat oleh ulama kontemporer seperti al-Baqillani bahwa rasm usmani adalah istilahi, yakni berdasarkan ijtihad para sahabat. Sehingga, rasm usmani bukan sesuai yang wajib diikuti. Boleh menuliskan al-Qur'an dengan kaidah 'Arabiyyah, boleh juga dengan kaidah rasm usmani yang ditetapkan pada masa Usman bin Affan. Al-Baqillani mengatakan bahwa nabi tidak pernah menyuruh para sahabat menulis dengan satu bentuk tulisan. Ada sahabat yang menulis dengan pedoman makharij al-huruf dan ada yang tidak menggunakan kaidah makhraj huruf. ${ }^{12}$

4. Diperbolehkan atau diwajibkan untuk orang yang tidak memahami tata cara penulisan al-Qur'an menggunakan tata cara penulisan yang mereka pahami. Hal ini berfungsi agar tidak ada kesalahpahaman. Namun, mereka ini juga diwajibkan mempelajari dan memahami rasm usmani. Upaya ini sebgai

\footnotetext{
${ }^{10}$ Subhi Salih, Mabahits fi 'Ulum al-Qur'an, 275.

${ }^{11}$ Muhammad 'Abdul Azim az-Zarqani, Manabil al-Irfan fi Ulum al-Qur'an, (Beirut: Dar al-Kutub al-'Ilmiyyah, 2013), 204.

${ }^{12} \mathrm{Az}$-Zarqani, Manabil al-Irfan, 212.
} 
wujud dari rasa hormat atas ilmu rasm yang telah ditetapkan oleh para pendahulu. ${ }^{13}$

Az-Zarqani juga pernah mengatakan bahwa model penulisan yang satu bentuk adalah kaidah yang diperuntukkan pada masa awal Islam saja. Namun, dengan perkembangan zaman dan makin luasnya ilmu, maka pedoman penulisan al-Qur'an untuk motif penyebarluasan al-Qur'an perlu menggunakan pedoman khusus, karena jika tidak dikhawatirkan akan terjadi kesalahpahaman. ${ }^{14}$

\section{Sejarah Penulisan al-Qur'an dari Manuskrip Mushaf Kuno ke Mushaf Standar Indonesia}

Penyalinan al-Qur'an di Nusnatara sudah berlangsung lama sejak abad XIII pada masa kerajaan samudera Pasai. Ada banyak manuskrip mushaf ditemukan di Nusantara, seperti Aceh, Sumatera, dan berbagai tempat lainnya. Beberapa manuskrip yang ditemukan tidak semua mengacu pada pedoman penulisan rasm usmani. Ada dua model penulisan al-Qur'an pada manuskrip yang ditemukan, yakni kaidah rasm usmani dan campuran usmani-imla'i. Beberapa manuskrip kuno yang ditemukan di berbagai daerah menjadi bukti bahwa tidak semua manuskrip mushaf tata cara penulisannya mengacu pada satu kaidah penulisan. Mushaf yang ditemukan dan diindikasikan sebagai mushaf tertua secara kaidah penulisan tidak mengacu pada kaidah rasm usmani. Misalnya manuskrip mushaf Salinan al-Faqih al-Salih Afif al-Din Abd al-Baqri pada tahun $1585 \mathrm{M}$, manuskrip yang ditemuakn di Ambon yang diperkirakan pada tahun $1590 \mathrm{M}$, serta manuskrip pada tahun $1731 / 1753$ yang ditemukan di pulau penyengat. ${ }^{15}$

Dari data tersebut menunjukkan bahwa kaidah rasm usmani sudah dikenal pada masa Islam awal datang di Nusantara, akan tetapi pedoman pastinya belum ada. Kemudian pada abad 20 mulai muncul lembaga percetakan al-Qur'an, seperti Lajnah Taftish al-Masahif al-Sarifah, Lembaga percetakan Afif Cirebon dan Salim Nabhan Surabaya juga menjadi pusat penyalinan mushaf dan penyebarannya. Mushaf-mushaf yang beredar di Indonesia dikatakan bahwa kaidahnya lebih cenderung pada kaidah Abu Amr al-Dani, hal ini dapat dilihat dari mushaf cetak Salim Nabhan dan Afif Cirebon tata cara penulisannya menggunakan rasm usmani.

Beberapa perbedaan yang terjadi pada manuskrip mushaf yang dtemukan adalah perbedaan rasm, seperti pada penerapan kaidah haif (membuang). Misalnya penyalinan kata العالمين. العلمين. Hengan menggunakan itsbat alif atau haर्\{f alif, menjadi bisa dilihat pada manuskrip yang menjadi koleksi perpustakaan Sonobudoyo, Radya Pustaka, Bayt al-Qur'an, serta mushaf al-Qur'an koleksi pondok pesantren Tebuireng yang menjadi objek tulisan ini. Selain itu, penyalinan dalam penggunaan tanda saktah ada yang menggunakan kode $\omega$, ada juga yang menuliskannya secara lengkap, yakni سكته

Dengan banyaknya beredar mushaf cetak menjadikan pemerintahan merasa perlu membuat legalitas pentashihan al-Qur'an. Sehingga, pada tahun 1974, mulai muncullah pentashihan mushaf al-Qur'an yang didominasi dari mushaf Bombay, Pakistan, dan Turki. Dari pengalaman melakukan pentashihan, maka Kementrian Agama membentuk suatu lembaga pentashihan al-Qur'an.

\footnotetext{
${ }^{13} \mathrm{Ibid}, 213$.

${ }^{14}$ Badruddin az-Zarkasyi, al-Burhan fi Ulum al-Qur'an, (Beirut: Dar al-Hadith, 2006), 208.

${ }^{15} \mathrm{Ali}$ Akbar, "Mushaf Kuno ternate Tertua di Indonesia: Menelaah Ulang Kolofon" dalam Jurnal lektur Keagamaan, Vol. 8 No. 2, 2010, 291.
} 
Pada tahun 1972, mulai ada perselisihan mengenai kaidah penggunaan rasm mushaf. Dari adanya perselisihan tersebut, maka muncul inisiatif membentuk lembaga resmi lajnah pentashihan al-Qur'an. Sehingga, pada tahun 1974, dibentuklah musyawarah kerja ulama ahli al-Qur'an guna membahas mengenai pedoman pentashihan yang dapat dijadikan pedoman bagi para penerbit dalam menggandakan mushaf al-Qur'an. Musyawarah kerja pertama kali ini, berhasil menghasilkan rumusan tentang pedoman rasm, harakat, tanda waqaf, dan lainnya yang kemudian disebut dengan Mushaf Standar Indonesia. Hasil perumusan ini disahkan dan dijadikan pedoman dalam percetakan dan penerbitan mushaf standar di Indonesia.

Pada tahun 1984, mushaf standar Indonesia telah disetujuai oleh para ulama dan dibukukan. Mushaf standar Indonesia ini bertujuan untuk menjadi rujukan utama dalam pentashihan mushaf dari seluruh al-Quran yang dicetak dan diterbitkan. Hal ini diperkuat dengan adanya Keputusan Menteri Agama No. 25/1984 serta Intruksi Menteri Agama No. 07/1984mengenai rujukan mushaf al-Qur'an dalam penerbitan alQuran. Adapun tujuan lain dibukukannya bentuk mushaf standar Indonesia adalah model harakat, tanda waqaf, tanda baca dapat diikuti oleh para penerbit, sehingga tidak ada lagi perbedaan bentuk yang menimbulkan perselisihan seperti yang pernah terjadi pada masa Nabi.

Mushaf Standar Indonesia mengalami perkembangan dengan pesat. Sejak diresmikannya mushaf standar Indonesia, banyak muncul mushaf yang menggunakan rujukan mushaf tersebut dari berbagai penerbit. Misalnya, dari Kementrian Agama sendiri menerbitkan 35.000 mushaf yang disebarkan ke seluruh Indonesia. Selain itu, di era saat ini yang sudah berbentuk digital, aplikasi al-Qur'an juga menjadikan mushaf standar Indonesia menjadi pedoman dalam penerbitannya

\section{Komparasi Perbedaan Rasm Surat al-Baqarah dalam Mushaf Kuno dan Mushaf Standar Indonesia}

Tulisan ini mengkaji tiga surat, yakni Yasin, ar-Rahman, dan al-Waqiah. Adapun langkah pertama yang dilakukan adalah inventarisasi kata yang menggunakan kaidah ba:f. Kaidah tersebut juga dilihat dari kaidah ad-Dani dan Abu Dawud. Adapun pengklasifikasiannya adalah sebagai berikut.

\section{Surat Yasin}

Ada sekitar 33 lafadz dalam surat Yasin yang mengandung kaidah haqf dari dua naskah mushaf al-Quran standar Indonesia dan mushaf Tebuireng. Dari beberapa kata tersebut, ada beberapa yang terjadi perbedaan antara keduanya

\begin{tabular}{|c|c|c|c|}
\hline No & MQT & MSI & Kaidah \\
\hline 1 & فأغشيناهم & فأغشينهم & $\begin{array}{l}\text { Harf Alif pada huruf ن yang bertemu } \\
\text { dengan dhamir }\end{array}$ \\
\hline 2 & احصيناه & احصينه & $\begin{array}{l}\text { Haaf Alif pada huruf نا bertemu dengan } \\
\text { dhamir }\end{array}$ \\
\hline 3 & أصحاب & اصحب & Haqf Alifpada Jama'Taksir \\
\hline 4 & 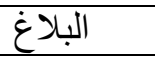 & البلغ & Haif Alif yang terletak setelah huruf lam \\
\hline 5 & باقوم & 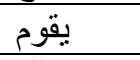 & Haqf alif pada ya' nida' \\
\hline 6 & ضلال & ضلل & $\begin{array}{l}\text { Harf Alif yang terletak di antara huruf } \\
\text { lam }\end{array}$ \\
\hline 7 & 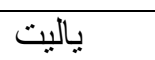 & يليت & Ha:f alif pada ya' nida' \\
\hline 8 & 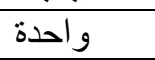 & واحده & Madzhab ad-Dani melakukan itsbat alif \\
\hline
\end{tabular}




\begin{tabular}{|c|c|c|c|}
\hline 9 & خامدون & خامدون & $\begin{array}{l}\text { Imla'I tidak menerapkan baরif alif pada } \\
\text { jama' mudzakar salim }\end{array}$ \\
\hline 10 & باحسرة & بحسرة & Haqf alif pada ya' nida' \\
\hline 11 & احيييناه & احيينها & $\begin{array}{l}\text { Haqf Alif pada huruf نا bertemu dengan } \\
\text { dhamir }\end{array}$ \\
\hline 12 & 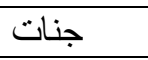 & جنت & Haqf alif pada jama' muannats salim \\
\hline 13 & 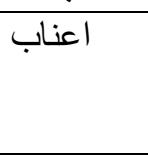 & 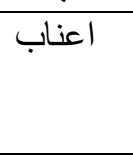 & $\begin{array}{l}\text { Haqf alif pada jama' taksir menurut } \\
\text { pendapat al-Dani itsbat alif, akan tetapi } \\
\text { menurut Abu Dawud havf alif }\end{array}$ \\
\hline 14 & سبحان & سبحن & $\begin{array}{l}\text { Lafadz yang mengikuti wazan نعلان } \\
\text { menurut al-Dani berlaku Itsbat alif, } \\
\text { kecuali pada satu lafadz ini }\end{array}$ \\
\hline 15 & قدرناه & قدرنه & $\begin{array}{l}\text { Harf alif pada huruf نا bertemu dengan } \\
\text { dhamir }\end{array}$ \\
\hline 16 & متاعا & متاعا & $\begin{array}{l}\text { Haqf alif pada setiap jama' yang mengikuti } \\
\text { wazan مفاعل akan tetapi al-Dani } \\
\text { melakukan Itsbat alif }\end{array}$ \\
\hline 17 & ضلال & 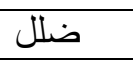 & Harf alif yang terletak di antara huruf lam \\
\hline 18 & صادقين & صدقين & Håf alif pada jama' mudzakar salim \\
\hline 19 & 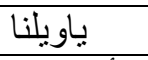 & يويلنا & Haqf alif pada ya' nida' \\
\hline 20 & أصحاب & اصحب & Ha\&f alif oleh al-Dani dan Abu Dawud \\
\hline 21 & فاكهون & فكهون & Håf alif pada jama' mudzakar salim \\
\hline 22 & 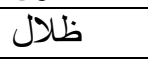 & 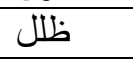 & Harf alif yang terletak di antara huruf lam \\
\hline 23 & فاكهة & فاكهة & $\begin{array}{l}\text { Ada khilaf dalam riwayat Abu Dawud, } \\
\text { namun yang lebih berlaku adalah havf alif. }\end{array}$ \\
\hline 24 & يابني & يبني & Håf alif pada ya' nida' \\
\hline 25 & لمسخناهم & لمسخنه & $\begin{array}{l}\text { Haqf alif pada huruf نا bertemu dengan } \\
\text { dhamir }\end{array}$ \\
\hline 26 & الكافرون & الكفرين & Haqf alif pada jama' mudzakar salim \\
\hline 27 & ذللناها & ذذلنها & $\begin{array}{l}\text { Haqf alif pada huruf نا bertemu dengan } \\
\text { dhamir }\end{array}$ \\
\hline 28 & الإنسان & الانسان & Madzhab ad-Dani melakukan itsbat alif \\
\hline 29 & خلقناه & خلقنه & $\begin{array}{l}\text { Harf alif pada huruf ن yang bertemu } \\
\text { dengan dhamir }\end{array}$ \\
\hline 30 & السموات & 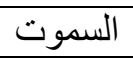 & Harf alif pada jama' muannats salim \\
\hline 31 & 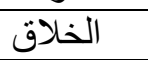 & 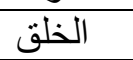 & Ha:f alif yang terletak setelah huruf lam \\
\hline 32 & فسبحان & فسبحن & $\begin{array}{l}\text { Lafadz yang mengikuti wazan نعلان } \\
\text { menurut al-Dani berlaku itsbat alif, kecuali } \\
\text { pada satu lafadz ini }\end{array}$ \\
\hline 33 & الأزواج & الأزواج & $\begin{array}{l}\text { Hasf alif karena jama' taksir dan disepakat } \\
\text { oleh Abu Dawud }\end{array}$ \\
\hline
\end{tabular}

Dari beberapa lafadz dalam klasifikasi rasm dari manuskrip mushaf Tebuireng dan Mushaf standar Indonesia ada beberapa perbedaan dan persamaan penggunaan 
rasm kaidah ha:f dan itsbat alif. Adapun perbedaan penggunaan rasm dalam dua mushaf ini dari beberapa kaidah ba: yakni:

1. Hasf alif pada pada huruf $\mathrm{L}$ bertemu dengan dhamir

Mushaf standar Indonesia dalam surat Yasin mengikuti kaidah tersebut, akan tetapi manuskrip mushaf Tebuireng tidak mengikuti kaidah ini. Adapun lafadz-lafadz yang menerapkan kaidah ini ada 7.

2. Hazf alif pada jama' mudzakar salim

Ada 3 lafadz dari mushaf standar Indonesia yang mengikuti kaidah ini dan tidak diikuti oleh manuskrip mushaf Tebuireng. Namun, ada pengecualian dari mushaf standar Indonesia yang tidak menerapkan kaidah ini, yaitu lafadz خامدون.

3. Harf Alif pada ya' nida'

Ada 5 lafadz dari mushaf standar Indonesia yang mengikuti kaidah ini, akan tetapi tidak diikuti oleh manuskrip mushaf Tebuireng.

4. Haif pada jama' taksir

Ada satu lafadz yang menggunakan kaidah ini, yakni lafadz اعناب dan. Akan tetapi lafadz اعناب mushaf standar Indonesia tidak menerapkannya, mushaf standar Indonesia lebih menggunakan itsbat Alif sama halnya dengan mushaf Tebuireng. Hal ini menunjukkan bahwa pada lafadz tersebut MSI dan MQT lebih sepakat dengan riwayat Abu Amr ad-Dani.

5. Haर्श alif yang terletak setelah huruf lam atau di antara dua huruf lam

Ada 5 lafadz dari mushaf standar Indonesia yang menerapkan kaidah ini. Ada dua yang menggunakan kaidah ba: f alif setelah huruf lam dan ada tiga yang ba: f alif di antara dua huruf lam.

6. Harf alif pada jama' muannats salim

Ada dua lafadz dalam mushaf standar Indonesia dan yang tidak digunakan mushaf tebuireng terhadap kaidah ini, yakni lafadz جنت dan السموت.

Adapun lafadz yang mempunyai persamaan dalam penerapannya adalah yang berkaitan dengan lafadz bilangan, seperti lafadz واحده. Kemudian, lafadz yang memiliki khilaf dari dari beberapa riwayat, yakni ad-Dani dan Abu Dawud, seperti فاكهة dan الانسان. Selain itu, ada satu lafadz lagi yang dua mushaf ini memiliki persamaan, yakni lafadz مناعان Apabila sesuai dengan kaidah, seharusnya lafadz yang mengikuti مفاعل cara penulisannya dengan ha:f, akan tetapi ada perbedaan menurut riwayat ad-Dani yang lebih menggunakan itsbat.

\section{Surat Ar-Rahman}

Ada 19 lafadz dalam surat ar-Rahman dalam penerapan kaidah haof atau itsbat alif, yakni:

\begin{tabular}{|c|c|c|c|}
\hline No & IQT & MSI & Kaidah \\
\hline 1 & الإنسان & الانسان & Madzhab al-Dani dengan melakukan itsbat alif \\
\hline 2 & فاكها & فاكهه & $\begin{array}{l}\text { Ada khilaf dalam riwayat Abu Dawud, namun } \\
\text { yang lebih berlaku adalah ha:f alif. }\end{array}$ \\
\hline 3 & 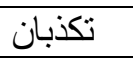 & تكذبان & Imla'i/harusnya haqf alif pada isim tasniyah \\
\hline 4 & بلتنقيان & يلتقين & Hazf alif pada isim tasniyah \\
\hline 5 & بيغيان & بيغنين & Hazf alif pada isim tasniyah \\
\hline 6 & المنشأت & المنشأت & Harf alif pada jama' muannats salim \\
\hline 7 & 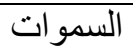 & السموت & Harf alif pada jama' muannats salim \\
\hline 8 & الثقلان & 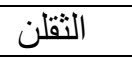 & Håf alif pada isim tasniyah \\
\hline
\end{tabular}




\begin{tabular}{|c|c|c|c|}
\hline 9 & بامعشر & يمعشر & Hazf alif pada ya' nida' \\
\hline 10 & جنتان & جنتن & Hazf alif pada isim tasniyah \\
\hline 11 & زوجان & 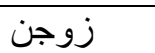 & Hasf alif pada isim tasniyah \\
\hline 12 & قاصرات & قصرت & Harf alif pada jama' muannats salim \\
\hline 13 & 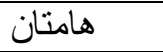 & 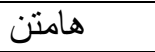 & Hazf alif pada isim tasniyah \\
\hline 14 & 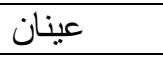 & عينن & Hazf alif pada isim tasniyah \\
\hline 15 & نضاختان & نضاختن & Hazf alif pada isim tasniyah \\
\hline 16 & 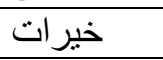 & خيرت & Harf alif pada jama' muannats salim \\
\hline 17 & مقصور ات & مقصورت & Harf alif pada jama' muannats salim \\
\hline 18 & 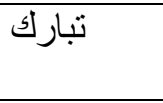 & تبرك & $\begin{array}{l}\text { Haaf Alif pada kata tertentu riwayat ad-Dani dan } \\
\text { Abu Dawud }\end{array}$ \\
\hline 19 & الجلال & الجلل & Harf Alif yang terletak di antara huruf lam \\
\hline
\end{tabular}

Ada beberapa lafadz dari dua mushaf ini yang terjadi perbedaan, yakni:

1. Haif alif pada isim tasniyah

Ada 9 lafadz yang menggunakan kaidah ini, namun ada satu lafadz yang ada dalam mushaf standar Indonesia tidak konsisten, yakni pada lafadz تكنبان.

2. Haif alif pada bentuk jama' muannats salim

Ada 5 lafadz yang menggunakan kaidah ini. Akan tetapi, ada satu lafadz yang ada dalam mushaf standar Indonesia dan mushaf Tebuireng tata cara penulisannya sama-sama melakukan ha:f alif, yakni lafadz المنشأت.

3. Haर्श alif pada ya' nida'

Ada satu lafadz yang menerapkan kaidah ini pada mushaf standar Indonesia, yakni lafadz يمعشر.

4. Ha:f alif pada lafadz tertentu dari riwayat ad-Dani dan Abu Dawud

Lafadz فاكها antara MSI dan MQT sama sama melakukan itsbat alif, namun pada lafadz تبرك mushaf standar Indonesia melakukan ha:f alif.

5. Ha: alif di antara dua huruf lam

Ada satu lafadz yang ada pada mushaf standar Indonesia menerapkan kaidah ini, namun mushaf Tebuireng tidak menerapkannya, yakni lafadz الجلل.

Selain dari beberapa kaidah di atas, ada satu lafadz yang menjadi perbedaan oleh para ulama tentang itsbat atau ha:ff, yakni lafadz الانسان. Kedua mushaf ini lebih cenderung mengikuti riwayat ad-Dani dengan melakukan istbat alif

\section{Surat Al-Waqiah}

Ada 32 lafadz dalam mushaf standar Indonesia dan mushaf Tebuireng dalam kaidah ha: alif, di antaranya adalah:

\begin{tabular}{|c|c|c|c|}
\hline No & IQT & MSI & Kaidah \\
\hline 1 & كاذبه & كاذبه & Hazf alif karena perbedaan qira'at \\
\hline 2 & 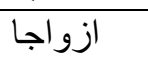 & 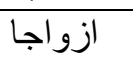 & 'Hazf alif pada jama' taksir \\
\hline 3 & نثلثة & ثلثة & Hazf alif pada bentuk bilangan \\
\hline 4 & فأصحاب & فأصحب & 'Hazf alif pada jama' taksir \\
\hline 5 & أصحاب & اصحب & 'Hazf alif pada jama' taksir \\
\hline 6 & السابقون & السبقون & Hazf Alif pada jama' mudzakar salim \\
\hline 7 & السابقون & السبقون & Hazf Alif pada jama' mudzakar salim \\
\hline
\end{tabular}




\begin{tabular}{|c|c|c|c|}
\hline 8 & 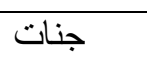 & جنت & Hazf Alif pada jama' muannats salim \\
\hline 9 & متقابلين & متقبلين & Hazf Alif pada jama' mudzakar salim \\
\hline 10 & 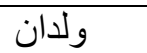 & 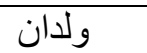 & harusnya hazf alif pada isim tasniyah \\
\hline 11 & باكو اب & باكو اب & 'Hazf alif pada jama' taksir \\
\hline 12 & فاكها & فاكهه & $\begin{array}{l}\text { Ada khilaf dalam riwayat Abu Dawud, namun } \\
\text { yang lebih berlaku adalah ha: alif. }\end{array}$ \\
\hline 13 & سلاما & سلما & Hazf alif karena perbedaan qira'at \\
\hline 14 & و اصحاب & و اصحب & 'Hazf alif pada jama' taksir \\
\hline 15 & فاكهه & فاكهه & $\begin{array}{l}\text { Ada khilaf dalam riwayat Abu Dawud, namun } \\
\text { yang lebih berlaku adalah hasf alif. }\end{array}$ \\
\hline 16 & انشأناهن & انشأنهن & $\begin{array}{l}\text { Hazf Alif pada huruf ن bertemu dengan } \\
\text { dhamir }\end{array}$ \\
\hline 17 & فجعلناهن & فجعلنهن & $\begin{array}{l}\text { Hazf Alif pada huruf ن bertemu dengan } \\
\text { dhamir }\end{array}$ \\
\hline 18 & لأصحاب & لأصحب & 'Hazf alif pada jama' taksir \\
\hline 19 & 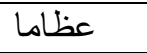 & عظاما & Hazf alif pada jama’ taksir \\
\hline 20 & 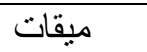 & 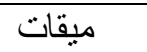 & Hazf Alif pada jama' muannats salim \\
\hline 21 & فنشاربون & فشاربون & Hazf Alif pada jama' mudzakar salim \\
\hline 22 & خلقناكم & خلقنكم & $\begin{array}{l}\text { Hazf Alif pada huruf ن bertemu dengan } \\
\text { dhamir }\end{array}$ \\
\hline 23 & 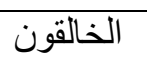 & الخالقون & Hazf Alif pada jama’ mudzakar salim \\
\hline 24 & لجعلناه & لجعلنه & $\begin{array}{l}\text { Hazf Alif pada huruf ن bertemu dengan } \\
\text { dhamir }\end{array}$ \\
\hline 25 & جعلناه & جعلنه & $\begin{array}{l}\text { Hazf Alif pada huruf ن bertemu dengan } \\
\text { dhamir }\end{array}$ \\
\hline 26 & لجعلناها & لجعلناه & $\begin{array}{l}\text { Hazf Alif pada huruf ن bertemu dengan } \\
\text { dhamir }\end{array}$ \\
\hline 27 & جعلناه & جعلنها & $\begin{array}{l}\text { Hazf Alif pada huruf ن bertemu dengan } \\
\text { dhamir }\end{array}$ \\
\hline 28 & بمواقع & 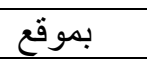 & Hazf alif pada jama' taksir \\
\hline 29 & العالمين & العلمين & Hazf Alif pada jama' mudzakar salim \\
\hline 30 & صادقين & صدقين & Hazf Alif pada jama' mudzakar salim \\
\hline 31 & فسلام & فسلم & Hazf alif karena perbedaan qira'at \\
\hline 32 & اصحاب & اصحب & Hazf alif pada jama' taksir \\
\hline
\end{tabular}

Dalam surat al-Waqiah ini, ada beberapa perbedaan dan persamaan mengenai penggunaan rasm, di antaranya adalah:

1. Håf pada jama' taksir

Ada 9 lafadz dalam mushaf standar Indonesia yang menggunakan kaidah ini dan sebaliknya pada mushaf Tebuireng. Akan tetapi ada pengecualian dari mushaf standar Indonesia yang tidak konsisten dalam penggunaan kaidah ini, yakni pada lafadz عظاما باكواب, ازوراجا.

2. Hazf alif pada jama' mudzakar salim 
Ada 7 lafadz dari dua mushaf ini dalam penerapan ha:f pada kaidah jama' mudzakar salim. Akan tetapi, ada beberapa lafadz yang dalam mushaf standar Indonesia tidak menerapkan kaidah ini, yaitu الخالقون dan فثشاربون.

3. Håf alif pada jama' muannats salim

Ada 2 lafadz yang menggunakan kaidah ini. Akan tetapi, ada satu yang mushaf standar Indonesia tidak menerapkannya, namun mushaf Tebuireng tetap menggunakan rasm imla’i dalam penggunaannya, yaitu lafadz ميقات.

4. Harf alif pada huruf ن bertemu dengan dhamir

Ada 7 lafadz yang menggunakan kaidah ini dalam mushaf standar Indonesia dan sebaliknya pada mushaf Tebuireng. Akan tetapi ada satu lafadz pada mushaf standar Indonesia menggunakan rasm imla'i, yakni lafadz لجعاه

Di samping penjelasan di atas, ada beberapa lafadz yang antara dua mushaf ini mempunyai persamaan dalam cara penulisannya, yakni pada penerapan kaidah pada lafadz yang menunjukkan bilangan, seperti lafadz ثلثنة. Selain itu, dalam kaidah yang terjadi khilaf ulama, seperti lafadz فاكها dalam mushaf standar Indonesia namun mushaf Tebuireng konsisten sama sama melakukan itsbat alif. Pada lafadz yang mempunyai perbedaan qira'at, harusnya menerapkan kaidah ha: alif, akan tetapi dua mushaf ini tidak menerapkan kaidah tersebut, seperti dalam lafadz كاذبه. Berbeda lagi pada lafadz سلما mushaf Tebuireng tetap melakukan itsbat alif, akan tetapi mushaf standar Indonesia menerapkan kaidah harf pada lafadz yang mempunyai bacaan yang berbeda.

\section{Penutup}

Dari pembahasan yang dijelaskan di atas, penulis menyimpulkan bahwa ada beberapa perbedaan dalam penggunaan kaidah hazf alif pada dua mushaf ini. Mushaf standar Indonesia banyak menerapkan kaidah ha: f alif, sedangkan mushaf Tebuireng banyak menggunakan bentuk itsbat alif atau lebih menerapkan cara penulisan imla'i. Beberapa kaidah yang ada pada mushaf standar Indonesia menerapkan ha: alif dalam surat Yasin, ar-Rahman, dan al-Waqiah adalah kaidah pada lafadz yang berbentuk jama' taksir, jama' mudzakar salim, jama' muannats salim, isim tasniyah, ya' nida', alif yang terletak setelah huruf lam atau di antara huruf lam, serta ketika ada huruf $ن$ bertemu dengan dhamir.

Namun, mushaf standar Indonesia juga ada yang melakukan itsbat alif pada beberapa lafadz pengecualian. Beberapa lafadz tersebut di antaranya adalah dalam lafadz yang menunjukkan bilangan, adanya kbilaf madzhab, terutama riwayat Abu Amr ad-Dani dan Abu Dawud. Apabila terjadi khilaf antara keduanya, mushaf standar Indonesia lebih cenderung pada penulisan yang melakukan itsbat alif. Selain itu, mushaf standar Indonesia juga melakukan itsbat alif pada beberapa lafadz pada kaidah jama' mudzakar salim yang berjumlah 3 lafadz. Kemudian, pengecualian pada bentuk lafadz jama' muannats salim sebanyak dua lafadz. Lafadz bentuk jama' taksir sebanyak 3 lafadz. Penggunaan itsbat alif juga ada pada bentuk lafadz isim tasniyah sebanyak 3 lafadz. Hal ini berbeda dengan Mushaf Tebuireng yang konsisten menggunakan bentuk itsbat alif pada kaidah-kaidah yang seharusnya ha: alif.

Dari klasifikasi penggunaan rasm tersebut, penulis menyimpulkan bahwa mushaf Tebuireng saat penyalinannya lebih cenderung berpedoman pada penulisan berdasarkan kaidah imla'i yang menekankan itsbat alif. Sedangkan mushaf standar Indonesia menggunakan bentuk campuran yang terkadang melakukan ha:f dan terkadang melakukan itsbat dengan berpegang pada dua riwayat, yakni riwayat Abu Amr ad-Dani dan Abu Dawud. 


\section{Daftar Pustaka}

A'zami, Muhammad Mustafa, (1978). Kuttab Nabiy. Beirut: al-Maktab al-Islamy.

A'zami, Muhammad Mustafa, (2003). The History of The Qur'anic Text from Revelation to Compilation. London: UK Islamic Academy.

Al-Suyuti, Jalal al-Din Abdurrahman, (1951). al-Itqan fi 'Ulum al-Qur'an. Beirut: Dar alFikr.

Ali Akbar, (2010). Mushaf Kuno ternate Tertua di Indonesia: Menelaah Ulang Kolofon. Jurnal lektur Keagamaan, Vol. 8 No. 2.

Amal, Taufik Adnan, (2005). Rekonstruksi Sejarah al-Qur'an. Jakarta: Pustaka Alfabet.

Az-Zarqani, Muhammad 'Abdul Azim (2013). Manabil al-Irfan fi Ulum al-Qur'an. Beirut: Dar al-Kutub al-'Ilmiyyah.

Madzkur, Zainal Arifin, (2018). Perbedaan Rasm Usmani: Mushaf Standar Indonesia dan Mushaf Madinah. Jakarta: Azza Media.

Salih, Subhi, (1997). Mabahits fi Ulum al-Qur'an, Beirut: Dar Ilm al-Malayin.

Sirajuddin, Didin, (2000). Seni Kaligrafi Islam. Bandung: PT. Remaja Rosdakarya.

Subhi, Salih, (1997). Mabahits fi Ulum al-Qur'an. Beirut: Dar Kutub al-'Ilmi.

Zarkasyi, Badruddin, (2000) al-Burban fi Ulum al-Qur'an. Beirut: Dar al-Hadith. 